\title{
Cultural Studies, Critical Theory and Critical Discourse Analysis: Histories, Remembering and Futures.
}

\author{
Terry Threadgold (Cardiff)
}

\begin{abstract}
In this paper I have explored some of the histories which inevitably connect, but also differentiate, critical discourse analysis and cultural studies. I have argued that both are strongly influenced by the versions of critical theory which have been characterised as 'postmodernism' and 'poststructuralism' and that both could benefit not only from some serious engagement with the several disciplines from which their interdisciplinarity is derived but also from some further in depth exploration of the critical theory which informs them and which they have often 'translated' or 'co-opted' in reductionist ways. I have also argued that the claims sometimes made for critical discourse analysis are inflated and that without serious ethnographies and attention to the theorisation as well as research of contexts those claims cannot really be sustained. On the other hand 'resignification' or the cultural politics of CDA are important agendas and we need to do much more work on establishing exactly how social change can be effected through the kinds of work CDA could do. My conclusion is that we need to reframe and recontextualise the ways in which we define and perform CDA and that that will involve bringing cultural studies and critical discourse analysis together in productive new ways with other disciplinary and theoretical formations and with proper attention to the new and different global and local contexts in which we work.
\end{abstract}

\section{$1 \quad$ Introduction}

Of the three key terms in the first half of my title, not one is ubiquitously well defined, or understood in the same ways, in the different national, global, disciplinary or interdisciplinary contexts in which each may actually be discursively or performatively produced and enacted. Cultural Studies has been defined as an interdisciplinary endeavour 'concerned with the analysis of cultural forms and activities in the context of the relations of power which condition their production, circulation, deployment and, of course, effects.' (Bennett 1998:60) This definition, broad as it is, might also cover a whole range of other kinds of disciplinary and interdisciplinary endeavours: media and communication studies, some forms of semiotics, and work in any of the many disciplines - e.g., Anthropology, Sociology, Education, Philosophy, History, Geography, Linguistics - influenced in the last twenty years of the twentieth century, and heavily critiqued and rewritten, by the same forms of critical and cultural theory that formed cultural studies itself. It is this kind of complexity that caused 
Angela McRobbie to talk of the 'messiness of cultural studies' (1992: 722). In all of these places certain theoretical assumptions are now taken for granted: a social constructionist view of language; the idea that realities and subjectivities are constructed in and by language; that subjects construct themselves and the worlds they inhabit in their everyday uses of language; that power relations are constructed and deconstructed through these processes; that what we call the social and culture are similarly constructed and deconstructed; that this activity is characterised by narrativity, that changing narratives, telling stories differently, might change the social world and that the goal of work on and with language is a politics committed to social change through what Eco (1979) would have called a semiotic labour on and with texts.

Media Studies, for example, if we allow that the media involve 'cultural forms and activities' through which power relations are constituted, in its current 'production, text, reception' model, fits Bennett's definition of Cultural Studies and is in fact often a part of what Cultural Studies does (Durham/Kellner 2001). Media Studies however as we shall see below does often include content and discourse analysis as part of its repertoire, something that is more rare in Cultural Studies.

What Cultural Studies (Grossberg/Nelson/Treichler 1992; Gray/McGuigan 1993; Bennett 1993; Morley/Chen 1996; Curran/Morley/Walkerdine 1996; Storey 1996) usually does not do is canonical literary texts, since it was set up historically in many places in direct opposition to the perceived class-based elitism of literary studies. Literary Studies (Valdes/Miller 1985; Rice/Waugh 1989) on the other hand, or English Studies in those places where that term has remained undeconstructed by postcolonial theory, also formed and rewritten under the influence of critical theory, actually now shares with cultural studies the understandings and theories of language I have summarised above. Cultural Studies is also remarkably lacking in history (Steedman 1992). It does offer varying kinds of engagement with critical theory (see below), at one time almost as much of a challenge to literary studies as cultural studies itself was, and engages in intermittent skirmishes with Critical Discourse Analysis: but 'discourse analysis' in Cultural Studies is derived from poststructuralist philosophies and theories and is not the same thing as Critical Discourse Analysis.

Critical Theory is also often characterised both within and without Cultural Studies as 'poststructuralism' or 'postmodernism' and increasingly seen as having to do loosely with 'a linguistic turn' in the human sciences (as described above) which had strong effects in Cultural Studies and which is now, for those who characterise it thus, either thankfully almost behind us or something that we should endeavour to forget, or a continuing problem (Norris 1992, 1993; McRobbie 1994). On the other hand, current forms of Critical Discourse Analysis are almost all strongly influenced by Critical Theory and have been consequently largely rewritten as enterprises in the same period that Cultural Studies has been coming to prominence and becoming institutionalised.

To be asked in this context to write about the relevance of Critical Discourse Analysis to Cultural Studies is therefore to ask for a good deal of clarification of some of these issues and then some hard decisions about relevance, pragmatics, and the new contexts in which we teach and learn. In my case, it has also forced me to remember the arguments I made in 1997 
about the issue of linguistics and critical discourse analysis in relation to feminist theory (Threadgold 1997). Why was it that feminist theory never used linguistics, unless of course the feminist theorists were linguists, and did poststructuralist forms of linguistics have anything to offer feminist theory? Theoretically, many of the issues are similar to the issues raised now by this question in relation to cultural studies. However, they now need rethinking in the context of nation states made porous by new technologies and economic globalisation, and at the local level, communities, and classrooms, reconstituted by flows of licit and illicit bodies, information and capital, in ways which we have hardly begun to theorise. Kondo (1990), Wilson/Dirlik (1995), Lowe (1996), Gordon (1997), Baker Jr., Diawara/Lindeborg (1996), and Saldivar (1997) are among the very few texts which have seriously begun to address these issues. We have become more or less adept in these contexts at re-imagining and homogenising our students as 'markets' to be attracted by lists of quality assurance defined 'aims and outcomes' promising economic benefit and a secure future. The question of the relevance of Critical Discourse Analysis to the teaching of Cultural Studies relates to a different kind of pedagogic agenda, one based on a vision for the future and a new narrative of what it is that we are about which needs to be constructed out of some of the complexities and confusions within which we now work, all of which have histories which also need to be remembered.

\section{On 'Adding' CDA to Poststructuralist Cultural Studies}

A recent book by Barker/Galasinski (2001) provides me with a complex but typical example of the way some of these issues play themselves out in practice: and of the difficulties and problems inherent in trying to separate cultural studies and critical discourse analysis (CDA) in their current forms in order to argue that what cultural studies does would be done better with 'the addition' of CDA. This is what the book argues. It is subtitled 'A Dialogue on Language and Identity', a focus with which I have much sympathy, especially since we are told that it resulted from events in the authors' biographies through which they found themselves respectively 'dislocated' culturally or positioned as 'legal alien' (2001: 22-23). Having recently experienced the first myself in a migration the other way, from Australia to Wales, and currently working on precisely these issues, I have found the book extremely valuable. That said, I want to explore for a minute the way it does its work, because it is symptomatic of the issues with which we have to deal in asking the question about CDA and Cultural Studies.

The first chapter is constructed as a review and summary of what Saussure, Barthes, Derrida and Foucault (critical theory) have contributed to the 'philosophy of language' currently informing work in Cultural Studies. It is both a 'position' chapter and an introduction (2001:2). But the critical theorists are not the only other characters in this narrative. Raymond Williams is compared to structuralism (2001: 4-5), Hebdige's (1979) semiotic work on youth culture with Paul Willis's (1977: 1978) commitment to ethnography (2001: 6-7), and structuralist work is seen as succeeded by audience and consumption studies, and a concern with the relationship between media and culture (2001: 7-8). There are two arguments here: first that work on the practices and beliefs of ordinary men and women is a form of progress 
beyond structuralism and semiotics, and second that although it involves 'talk' and 'speech texts' (2001: 8), none of this work shows any evidence of 'detailed language analysis'.

The reading of 'Poststructuralism and the Crisis of Representation' which follows begins with the critique of ethnography (Clifford/Marcus 1986), which rewrote it as a literary genre and a conversation, but could not use the tools of structuralist semiotics because by then these 'were the subject of attack by Derrida and poststructuralism' (2001: 9). An account of Derrida's critique and influence follows and its tenets (p. 21) are generally accepted by the authors with the difference that they see this kind of work as having produced a 'high textualism' which rejects any kind of 'ethnographic or empirical work' (2001: 11). Derrida's influence in cultural studies, feminisms, postcolonial theory and new Marxisms is acknowledged but his influence is argued to have been 'not wholly benign' and is said to have 'little practical use' politically, being a 'new language' intelligible only to 'an elite intelligentsia' (2001: 11-12). First, Derrida has always understood that deconstruction cannot escape empiricism (Spivak 1988: 292) and argued that the politics of deconstruction is precisely about unsettling, displacing hegemonic conceptual systems in order to effect social change. (1972/1982: 329). Let me quote Derrida here:

I do not believe I have ever spoken of "indeterminacy" whether in regard to "meaning" or anything else. Undecidability is something else again. ... I want to recall that undecidability is always a determinate oscillation between possibilities (for example, of meaning, but also of acts). These possibilities are highly determined in strictly concern situations (for example, discursive - syntactical or rhetorical - but also political, ethical etc.) They are pragmatically determined. The analyses that I have devoted to undecidability concern just these determinations and these definitions, not at all some vague "indeterminacy". I say "undecidability" rather than "indeterminacy" because I am interested more in relations of force, in everything that allows, precisely, determinations in given situations to be stabilised through a decision of writing (in the broad sense which I give to this word which also includes political action and experience in general. (1988: 148)

It is because some people have understood Derrida's 'new language' as being about many of the things proponents of CDA regard as a crucial part of a cultural politics and have been prepared to struggle with language in order to unsettle the huge stabilities of discourse that feminists, postcolonial theorists, queer theorists and other radical groups have in fact found deconstruction to be of immense political value. The very politics of identity which is developed in Barker/Galasinski could not have been articulated without the 'new'/difficult 'language' that deconstruction provided. They argue themselves after all for a cultural politics involving writing new stories with 'new languages' (2001: 61). It is too easy then to repeat the cliches about Derrida whose most recent writings on Algeria, globalisation/peace, continue to give the lie to the argument that deconstruction lacks political usefulness (2002)/if we, the proponents of CDA are not prepared to struggle with 'new languages' when we find them we have to ask who out there will be so prepared?

In Barker/Galasinski an account of Foucault follows the critique of Derrida, with the criticism that his work has been used more 'to inspire studies of ... discipline' than ... 'power to' (2001: 14), that it does not, in other words, provide a theory of agency. Wittgenstein/Rorty are then 
introduced as the antidote to poststructuralism because in their work a certain kind of pragmatism plays a large role/shows how 'the endless play of signification' is stabilised in actual practice/everyday life (2001: 14-18). Ethnography is rehabilitated for continued use/CDA is introduced (rewritten as sharing a good deal with the cultural studies described earlier). CDA is presented as a theory offering the 'potential for a systematic/repeatable insight into the linguistic form capable of unravelling social practice' (2001: 25). On the other hand cultural studies, without CDA, has been 'unable to show precisely how the discursive construction of cultural forms is achieved in everyday life' (2001: 27). There are elements of this narrative which I would want to contest and I will return to them below.

Chapter 2 is an account of a kind that is much rarer in CDA. On language, identity and cultural politics, it reviews and introduces a wide range of complex theories of the subject from Foucault and Lacan to Stuart Hall, Judith Butler, and Laclau. It covers feminist work on the body, questions of culture and biology and performativity. But again there are antidotes provided to the perceived failure of poststructuralist theories of the subject to provide a theory of agency or to account for the way in which social change might actually happen: personal construct psychology, Wittgenstein, Rorty, and Giddens. This is a complex chapter which ends with a discussion of the cultural politics of language and identity (2001: $56 \mathrm{ff}$.) and the argument that these things are best studied 'not in terms of philosophic argument', 'or as the signs of dead texts alone' but by exploring the ways in which 'identity claims are achieved in day to day linguistic encounters' (2001: 61). The chapter is, like the first, very dependent on the poststructuralist work it attempts to rewrite as a pragmatics for linguistic work. However the poststructuralist influence also changes fairly radically what CDA looks like in this book, at least in terms of the ways in which the linguistic tools in chapter three are framed. This becomes a CDA that is much more in tune with the issues current in contemporary cultural studies and one which explicitly addresses the issue of the need for new theories for new realities discussed above.

It is interesting that it is to Rorty that the authors turn for a theory of rewriting, what they call a 'politics of re-description':

The language of cultural politics brings oppression 'into view' and expands the logical space for moral and political deliberation. This does not involve the discovery of truth, or less distorted perception in opposition to ideology, but the forging of a language with consequences which serve particular purposes and values as part of an evolutionary struggle which has no predetermined destiny. Cultural politics does not need essentialism or foundationalism but 'new languages' in which claims for justice do not sound crazy but come to be accepted as 'true'.... (2001: 57)

The lessons of poststructuralism have been well learned here, embodied in the list of what cultural politics is not, although it is Rorty's theory that is being discussed. This in turn is critiqued for its failure to analyse power or to employ sociological analyses of 'the institutions and organisations which produce and distribute cultural texts' (2001: 58-59). In relation to the second, parallels are drawn with Bennett's (1998) critique of cultural studies for 'displacing its politics onto the level of signification and texts' (2001: 59) and failing to deal with the same issues. West's (1993) methods for cultural politics are then listed as: deconstruction, 
demythologisation ('mapping the social construction of metaphors that regulate descriptions of the world') and demystification ('a partisan analysis of the complexity of institutional and other power structures' to reveal possibilities for social change and to link new theory to communities and networks of real people) (2001: 58). It is the last which both Rorty and cultural studies are seen to lack. I comment here only in passing that theories of rewriting of at least equal value to this enterprise could have been developed from feminist, postcolonial and queer theory as well as new Marxisms.

Despite the dominance of poststructuralist theory in the above, when we reach chapter 3 'Tools for Discourse Analysis', and despite the acknowledgement of the self-reflexivity required of the analyst, and the inclusion of intertextuality as a feature of text, CDA looks pretty much like a standard summary (a good one) of the theories of language we have become familiar with above and Hallidayan functional linguistics. There is a nod towards CDA as itself theory, but it is claimed now to provide a methodology which is replicable, systematic and verifiable. This return to the language of the social sciences and of social science research methods text-books is interesting. I think there are good reasons why CDA can never really be all of these things and they have to do, as Halliday himself argued (Threadgold 1997: $104 \mathrm{ff}$.), with the ineffability of grammatical categories and the differences between a grammatics as metalanguage and the actual textures of language in use. In this it compares with most social science research methods and poststructuralist ones with the difference that the latter acknowledge the difficulties of making such claims. While I would use the same kind of checklist of tools as is used here, I would also want then to theorise them (of which more below).

The difficulties inherent in making such claims are nowhere more clear than in the two case study chapters (Barker/Galasinski 2001, chs. 4 and 5). Each is rich and detailed in its reading of masculinity and ethnicity as constructed in everyday linguistic performance, but neither in fact uses very much of the apparatus set up in chapter 3 as a replicable methodology. Both depend to a large extent on the experience and erudition of the researchers, and would in fact be difficult to replicate precisely, although I take the point that the very theories of language we work with assume that language is a patterned and systematic phenomenon, that similar texts will occur in other contexts, and that some of the same kinds of results will be likely if similar questions are also asked of the texts. My point is that a great deal of interpretative work goes on in such analyses, whether at the level of deciding which grammatical category is most significant for this set of texts, or of mapping the texts onto contexts by looking at larger structures like language and religion (Barker/Galasinski, ch. 5).

For example, this analysis focuses on agency structures in the narratives about ethnicity, deciding to use transitivity, but making conscious decisions to ignore the 'explicit inscription of blame' in favour of 'the ascription of responsibility in a linguistic sense' (2001: 145). That decision can only come from the researchers' knowledge and experience of this population and the texts they are analysing: 'blame was expected to be laid by the Poles on the Ukrainians' (p. 145) and so was of less interest. A structuralist analysis might have called this a foregrounded choice. That these are interpretative and context-bound decisions would be to 
be expected from a theorisation of the identities, the subjectivities and habitus of the researchers, but that precisely makes them unlikely to be entirely replicable. And indeed if we look at the review of other work on the linguistic markers of ethnicity with which the chapter begins we find that Wodak et. al. (1999) and Meinhof/Galasinski (2000) have already made distinctively different kinds of interpretative choices in their analyses of the discourses and narratives of ethnicity in other contexts. None of this should be surprising in terms of the theories of language and identity which the book sets up as its framework in its early chapters. Nor do I see the inevitability of interpretative differences in the doing of CDA as a problem. Part of the richness of such analyses is in what can be seen and read from different perspectives. However these differences do not sit easily with arguments about objective, systematic, replicable and verifiable social science methodology.

The question of the performance here of text/context relations is also interesting. The researchers argue very convincingly for their analysis as demonstrating an anti-essentialist view of ethnicity which is context-bound and associated with living in a particular community (2001: 129, 135). Yet the context is in fact constructed by the researchers as a fairly narrow (and textual) account of a history related to the second world war and its aftermath: publications made available by the community council and a historical debate in a local newspaper (2001: 128). On the other hand the knowledge of the way language and religion or working practices contribute to the contradictory constructions of ethnicity in the narratives is largely read off the narratives themselves, historicised and projected into the community context as evidence of the context-bound nature of the constructions (e.g., 2001: 135). That is, there is no obvious demystification in West's (1993) sense of sociological analysis of institutions and community practices independent of the textual analysis. The interview texts are 'read' with some of the tools of CDA, but overall the reading does not look so very different to the kind that might be done by sociologists or anthropologists without the trappings of CDA.

There is no overt reference to intertextuality, or to the ways in which the interview data contributes to an understanding of the discourses, genres or narratives of ethnicity current in this particular context, nor is the positioning of speakers in and by those discourses, genres and narratives explicitly theorised in relation to institutional, organisational and family contexts, and what Halliday would have called the social semiotic of material histories, geographies, languages and religions, for example. Such a framing might have engaged in a different kind of analysis and understanding of the production of heteroglossic and dialogic texts and of 'fluid multiple identities' than that which is given here when the focus is on ethnic identity as 'the achievement of speaking subjects' (2001: 149). That is, the attempt to argue for CDA against, or in addition to, poststructuralist cultural studies seems in fact to have failed at the level of deconstruction too, in that it has looked at the binary positioned, disciplined subject/agency, and opted almost entirely for agency, under-theorising the ways in which the speakers are also spoken by the discursive, narrative and generic intertexts which construct them as they construct their identities. In fact it seems to me that the deconstruction would involve seeing agency as always being about being both multiply positioned and agentive 
simultaneously. That is why as speakers we have conscious control over generic structures but not over the fragments of intertext we chunk together to make texts.

The analysis also makes no attempt to build in, in any other than implicit ways, any of the theorising of the body that is evident in the earlier poststructuralist part of the book. How do these discourses and narratives form and brand bodies in these ethnic encounters? How do we link the materiality of the texts of the interviews to corporeality? Judith Butler's work on performativity is used here but the non-textual body is not very much in evidence except in so far as we know that the texts were produced by members of a 'real' community.

I am being too critical here of work which in fact I admire. My point is that even here the differences argued to exist between CDA and cultural studies in relation to explicitness and replicability are not very great. I have deliberately used a more explicit metalanguage of the kind I myself have used about intertextuality, to show how another CDA researcher might formulate the same issues, but also to argue that some such explicit metalanguage, or an agreed set of them, needs to be in place before we can make large claims about the replicability of our CDA methods or their great advantage over other approaches to textuality.

In what follows I will continue to move recursively back and forth between poststructuralist and CDA approaches in order to establish what each seems to offer before reaching some conclusions and answers to the question of the relevance of CDA to cultural studies.

\section{Some Digressions on Intellectual Histories and Myths}

Having examined in detail a piece of research which is the product of the complexities I am exploring here, I want to turn back to my narrative of cultural studies and pick up on some of the undeconstructed binaries that seem still to haunt us. Once Cultural Studies had constituted itself as separate from Literary Studies, it remained the subject of disciplinary disputes which have left their marks on its own cultural formation and activities. Despite its desire to distinguish itself from literary studies, many of its earliest proponents received their training in the literary field, and critical theory, also influential in literary studies, was dominant both in its formation and in its typical modes of analysis. I will characterise what I mean here by 'critical theory' as the poststructuralist/postmodernist work of Bakhtin, Barthes, Kristeva, Freud, Lacan, Foucault and Derrida to name just a few and associate it with a critique of structuralism, enlightenment values and empiricism among other things. However I want to be very clear that a critique or a deconstruction of these things does not involve the rejection of them. It often involves a complex understanding of the ways in which they are embedded in our modes of thinking and being and cannot be avoided.

As a consequence of that critique, cultural studies' modes of research and analysis remained textual and literary/philosophical in their derivation, and were largely humanities based. They involved various forms of critical reading practice, informed by the theories which drove them: e.g., psychoanalytic or deconstructive readings. Ideologically, this inheritance plus the critique of structuralism and empiricism produced research positions which were apparently opposed to the explicit articulation of methodology, as part of a resistance to disciplinary purity and to any easily identifiable disciplinary location. This is not to say however that there 
was no methodology, or that it is impossible to articulate it. Increasingly, in order to teach cultural studies in this mode, and to satisfy publishers who wanted to produce saleable textbooks, methodologies had to be produced. Axelrod/Cooper (1993) Reading Critically, Writing Well and Schirato/Yell (1996 and 2000) Communication and Cultural Literacy are cases in point produced in the USA and Australia respectively. The other context where reading strategies (of both literary and cultural studies kinds) were being made explicit was of course in education and literacy studies where both deconstruction of current practice for political purposes and explicitness for improved teaching practice (in the sense of taking apart in order to understand) were common and important interventions (Luke/Freebody/Gilbert 1993; Luke 1997). In more theoretical mode, Barbara Johnson in her introduction to Derrida's Dissemination (1981) demonstrates very effectively how it is possible in each of Derrida's texts, to outline his methodology and that these methods are in fact linguistically and rhetorically based, even when he is using linguistics and rhetoric to deconstruct the premises on which they themselves are based. And there are many accounts by those who are critical of cultural studies methods of just exactly how they work (e.g., Hunter 1992; Steedman 1992).

The question of empiricism versus textuality is connected to the issue of methodology and also needs some unpacking here. This binary opposition is an interesting one and one that I will gradually attempt to deconstruct in what follows. It surfaces in Barker/Galasinksi (2001) in the consistently positive values given to everyday life and talk over writing or text, despite the fact that everyday life is then reduced to text for purposes of analysis. It is very clear that the complex interactions between the discursive and the material, between language and the corporeal, between geographies, institutions, bodies and texts, are the stuff that cultural studies must investigate, and that not enough attention has been paid to the non-discursive aspects of these assemblages. What poststructuralist theory has argued is that the empiricism/textual binary must be deconstructed, that writing does not (mis-)represent speech as some pure and originary form, that both speech and writing are forms of writing in the complex sense Derrida gives that word above. To suddenly then privilege the empirical over the textual as part of a critique of the poststructural is an unworkable reversal, rather than a deconstruction, of the binary. McRobbie (1992: 730) is right that: 'The site of identity formation in cultural studies remains implicitly in and through cultural commodities and texts rather than in and through the cultural practices of everyday life' and Butler's work (1990, 1993 ) is a prime example of why work on cultural practices needs to be done but it needs to be done in ways which understand and theorise the complex networks of materiality and textuality within which cultural practices are performed and enacted, not simply by privileging speech again.

Why for example is collecting texts in communities (by way of interviews, focus groups etc.) more 'empirical' than collecting texts in libraries, on the internet, from newspapers? What is collected remains 'textual'. Once it becomes empirical 'evidence' rather than text, we see again the privileging of speech over writing. This is one of the ways texts enter into the 'relations of ruling', what Smith has called textually mediated social organisation (Smith 1990) to which, as she argues, 'sociology has been extraordinarily blind', rarely attending to the 'documentary or textual process as such'. (Smith 1990: 209). There are positive signs that this is no longer 
the case (Kitzinger 1998 ; Cameron 2001) but we should be wary, from a sociological perspective, of referring to the complexity of Derridean deconstruction, or Foucauldian derived 'discourse analysis', for example, as being merely 'textual', simply because they begin their work with (often written) texts.

If we return then to the constitution of cultural studies, it was precisely this empiricism/text binarism that marked the arrival of Sociology and Anthropology, disciplines which had hitherto seen 'culture' and the 'social' as their territory, in this newly formed interdisciplinary space. It was here that the problems to do with the practical effects in cultural studies of the so-called 'linguistic turn' of critical theory, the supposed claim that 'everything is discourse', were first raised as an issue: and while, as I have suggested above, I do not believe that this is the only way for that 'linguistic turn' to be read, it is certainly the case that in the popularisation and enactment of its theoretical positions in textbooks and classrooms, and in summarising histories like that in Barker/Galasinski (2001), the complexity of the original theory (see Threadgold 1997, 2000) was lost in favour of a litany of concepts which had lost their original power and complexity and produced research remarkably lacking in history and context (Steedman 1992; McRobbie 1992). Thus terms like: signs, codes, representation, narrative, genre, intertextuality, myth, metanarrative, deconstruction, trace, supplement, subjectivity, habitus, identity, race, gender, class, sexuality and so on proliferate as metalanguage but with very little sense of the histories which produced them or of prior historical moments in which similar concepts and research have circulated. My criticism here can be compared to Curran's (Curran/Morley/Walkerdine 1996) account of the institutionalised 'forgetting', 'revisionism', involved in narratives of media audience research.

Nor has there been any attempt in the teaching of recent cultural studies to provide knowledge of the contexts, and of methodologies for researching them, which would make sense of all the textual work the metalanguage gives rise to. I am thinking here of the contextualising work that could be done in courses on critical theory, political science, history, economics, geography, sociology and so on. It is in the 'interdisciplinary' absence of this disciplinary context that criticisms of the anti-method stance have to be taken seriously. Cultural Studies has rejected on these grounds quantitative studies (e.g., content analysis), survey methods and questionnaires in favour of what Lewis called 'microscopic, semiotic or literary deconstruction of specific media texts' or qualitative (but not textual) analysis of audience reception of media and other texts (Williams 1999). McRobbie (1992) points to the absence of sociology in the Grossberg et. al. (1992) anthology of cultural studies, in many ways a defining text, and the failure to think, post-Marxism, which like the disciplines had come in for both poststructuralist and postcolonial and feminist critique, about a transformative social politics. In 2003, ten years later, it seems to me that that task is even more urgent as multicultural societies and globalisation force us to ask a lot of very hard questions about the meaning of 'critical' and for whom, about who gets to speak for whom and about how we re-theorise the constantly changing networks of textual and material relations in which we work. 
The very binary alternative to the metalanguage of cultural studies is to insist on the reality of the material world and the need to research it, empirically, providing recognisable kinds of evidence, using widely accepted 'research methods for the social sciences' which can be codified and replicated. Media Studies, situated as it is both within and outside Cultural Studies, like Linguistics, in its institutional UK forms at postgraduate level, has largely adopted the social science rather than the humanities trajectory. This may well have not a little to do with current ESRC funding arrangements and support for research methods courses of particular kinds in graduate contexts in UK universities. But it also has quite a lot to do with producing the current lack of any convincing body of media theory in the field. The fragmentation of research methodology produced in research methods courses, again without contexts, this time any detailed knowledge of the disciplines from which the methods come, is exacerbated at undergraduate level where as Williams pointed out some time ago, the influence of the cultural studies textual/deconstructive paradigm and its parallel focus on subjectivity left students without any 'research tools that might help build a picture of the world that is verifiable and representative' (Williams 1999: 277). The work of the Glasgow Media Group provides a notable exception to the claim that we lack a convincing media theory (Eldridge (ed.) 1993; Miller et. al. 1998; Philo (ed.) 1999), bringing together both kinds of approach - the social science methods and sophisticated understandings of language, text and discourse -in interesting and productive ways. However the kind of complexity involved in books like The Circuit of Mass Communication (1998) is not readily accessible to students when research methods are taught separately from disciplines, without critical theory to explain or challenge their connections and implications, and without some basic understandings of the role of textuality in the use of the methods themselves.

The work of the Glasgow media group deconstructs the binary distinction between the social and human sciences that I have constructed above as indeed does work in a number of other areas in cultural studies and as we shall see in critical discourse analysis itself. Production studies in television and theatre (performance studies, like media studies and communication studies, overlaps with cultural studies), and audience studies within cultural studies and media studies seem always to have drawn to some extent on both traditions (Tulloch/Moran 1986; Ang 1996; Threadgold 1997; Tulloch 2000; Tulloch 1999): but there is an uneasy truce here which continues to surface in relation to Critical Discourse Analysis and to some extent explains why it has not been taken up in dominant forms of Cultural Studies. It remains, for the critical theorist, a slightly suspect form of empirical social science methodology in a field which encompasses feminisms, queer theory, postcolonial theory and is still strongly influenced by an interdisciplinary anti-social science method stance, and it is often, for the social scientist, too closely connected to the problems of the 'linguistic turn' in cultural studies to be a viable option.

I have rehearsed these histories, and challenged some of the myths which they narratively produce, albeit in a somewhat cursory and broad-brush fashion, in order to situate the question of where, and whether, Critical Discourse Analysis might be useful to cultural studies and to locate the difficulties inherent in arguing that it could or should be useful in that 
space. But however we may, in the end, argue for the value of CDA, there are many other lacunae in cultural studies current armoury.

\section{$4 \quad$ What is Critical Discourse Analysis?}

We have seen one example above of what Critical Discourse Analysis can look like (Barker/Galasinski 2001). Let me begin again here with an account of what Critical Discourse Analysis is not. It is not the collocation of terms now common in cultural studies research to which I referred above, terms which have lost their histories in the translation into a cultural studies where one suspects that few, any longer, ever actually read the primary texts and research from which they were derived. These terms: representation, intertextuality, genre, narrative, discourse, performativity, corporeality, habitus, to name just a few are all used to support and argue a constructionist paradigm, that social realities and selves/bodies are constituted in discourse, and that social change requires both a deconstruction of the way these categories work and a rewriting of them to produce change. For those who are not linguists, or proponents of critical discourse analysis, this mode of operation with and on texts is seen as being primarily about language and representation, a form of, albeit poststructuralist, 'discourse analysis'.

The problem with the current uses of these tools of analysis is that in fact they have very little connection with the intricacies of language as such: they are macro not micro categories of analysis. They are large categories, identified with equally large chunks of often undeconstructed text. Once nominalised, they can be bandied about as names for things which apparently exist, but the work which would have to be done on the materiality of language to demonstrate that existence in recognisable and replicable linguistic terms is rarely done. Fairclough's $1995 \mathrm{a}$ and b) work on what the linguistics of intertextuality might look like and my own (1997) work on discourses of race and gender and with Kress (Kress/Threadgold 1998) offer examples of what might be necessary here. The terms have also in crucial ways become, in the translation into cultural studies, predominantly tools for the analysis of the textual or the discursive (understood as language and sometimes the visual). I want to suggest that this completely elides the radical potential of the poststructuralist vocabulary as it was framed and contextualised in the texts in which it was first developed.

I have argued elsewhere (Threadgold 2000) that the now linear narrative of the overthrow of structuralism by poststructuralism needs to be rewritten in terms of the discontinuities and anticipations of the very complex histories that are actually involved. Much radical poststructuralist work was anticipated by structuralist linguists: and poststructuralism constructs itself always in relation to the inevitability and centrality of structuralism (Derrida 1972/1982; 1978/1981). There is also no longer a clear distinction between Critical Discourse Analysis (CDA) and poststructuralist theories and concepts, as the latter have increasingly been used to theorise and reposition linguistic work of the kind that locates itself within the CDA paradigm. However, here, as in cultural studies, there has often been a tendency for the incorporation of poststructuralist concepts and analytical terms to be assimilated to the linguistic or the discursive. 
I want now to locate CDA historically and then return to the poststructuralist vocabulary in order to try to see what radical moves have been written out of its translation into both cultural studies and CDA itself. I then want to argue that it is not just a question of adding CDA to the current mix available in cultural studies but rather of rethinking both in relation to the work cultural studies and its affiliated disciplines and interdisciplines need to do in the twenty-first century.

CDA has several histories and emerges from a conjunction of different kinds of discursive activity. Critical Linguistics was an approach developed by a group based at the University of East Anglia in the 1970s (Fowler 1981; Fowler/Kress/Hodge/Trew 1979). The group was strongly influenced by the work of the linguist Michael Halliday and his systemic functional grammar although they also used stylistic approaches borrowed from Chomskeyan transformational linguistics and Fowler in particular used the work of Barthes and early French semiotics. They distinguished their approach from sociolinguistics and from the then mainstream paradigm of linguistics (which was Chomskeyan), refusing the oppositions form and content, and system and process or use, insisting on analysing real texts and their relations to real contexts. It is also important here to recognise the influence of Prague School linguistics and semiotics, British structuralist-functionalist anthropology, the work of the educational sociologist Bernstein (whose later (1990) work is specifically on pedagogic discourse) and the much earlier work of the linguists Sapir (1921) and Whorf (1956) in the work of Michael Halliday himself (Halliday 1985). This intertextual and discursive history needs to be thought of as still operating, albeit at a distance, in the work on discourse of this school of linguists.

Critical linguistics was concerned to read the meanings in texts as the realisation of social processes, seeing texts as functioning ideologically and politically in relation to their contexts. This was very much an approach in which discourse was text, but there was too little emphasis on the production and interpretation of texts, a too ready assumption of the transparent relationship between textual features and social meanings and a neglect of discourse as a domain of social struggle or of the ways in which changes in discourse might be related to wider processes of social and cultural change. There was also a typical Marxist top-down view of ideology and power and an emphasis on social structure rather than social action, social reproduction rather than social transformation (Fairclough 1992).

The work of the group that came to be known as social semioticians in Australia in the 1980s and 90s included some of the same people - Halliday, Hasan, Kress and Hodge - and worked with some of the same ideas, but in the Australian context there was a strong influence from poststructuralism and French structuralism and semiotics as well as the work of semioticians like Umberto Eco (1979), and a variety of feminisms, so that what Halliday had called a theory of language as social semiotic became something quite other by the early 1990s. There was a concern to rethink functional linguistics in the light of the work of Foucault on discourse, institutions and power, Bakhtin on heteroglossia and dialogism and the work of psychoanalytic feminisms on the unconscious and the questions of the body and subjectivity. There was a new focus on processes of textual interpretation and production, and a new 
understanding of the crucial importance of intertextuality and subjectivity in those processes as discursive processes involving struggle and change. What remained of the original theory was the importance of a functional theory of language as a way of grounding discourse analysis in a flexible linguistic analysis and a recognition of the importance of trying to integrate this with radical social and cultural theory. The work of Kress/Hodge (1988), of Kress/Threadgold (1988), of Thibault (1991), of Poynton (1985), the collection edited in 1988 by Birch/ O'Toole, Threadgold (1997) and the collection edited in 2000 by Lee/Poynton give some indication of the range, breadth and difference of this work from the earlier critical linguistics. The special issue of the journal Social Semiotics devoted to feminist poststructuralist work using functional grammar (Vol.3, No.1, 1993) is another example. Schirato/Yell (1996) was the pedagogic text-book version of this work, which was used as a text-book to teach students in education, cultural studies and semiotics in Australia. This text, much earlier than Barker/Galasinski (2001) combined poststructuralist theory and cultural theory with a functional linguistics.

Reflecting on it now, what is interesting about this work, despite the fact that some at least of its proponents were also very active in the National Australian Association of Cultural Studies at the time, was that it was seen as work in social semiotics, not cultural studies and was not anthologised in any of the collections of Australian Cultural Studies that define the field although when I left Australia the then President of the National Cultural Studies Association, Kay Schaffer, delivered a keynote address in 1999 in which she farewelled both myself and John Frow as having been major contributors to the field (Schaffer 2000). The Lee/Poynton (2000) book was published in the Australian Cultural Studies Series edited by myself and John Tulloch because at the time we were as editors committed to introducing new methods to cultural studies (see also Tulloch/Lupton 1999 where quantitative work was the issue). It is also notable that in the Grossberg et. al. (1992) account of Cultural Studies, while there are chapters which lament the absence of sociology and history, and which argue that the language theory available in cultural studies is inadequate to what it has to do (Steedman 1992), no-one remarks on the absence of linguistics or critical discourse analysis. Steedman's (1992) remarks on the detrimental effects of interdisciplinarity and intertextuality as methods of teaching history, used and popularised she suggests because they required less training and are thus cheaper, could it seems to me be extended to cover the decline in disciplinary rigour and the failure to teach critical theory and linguistics/CDA itself in recent cultural studies contexts.

Norman Fairclough's work in Britain is among the first to actually use the label CDA (Fairclough 1995a). Fairclough used this Australian work (Kress/Threadgold 1988; Thibault 1991) when he produced a theory of discourse and social change, drawing on Foucault and a number of neo-Marxist and other social theorists, that did bring together a version of functional linguistics with sophisticated social and cultural theory. Pecheux (1982) whose approach to discourse was strongly framed by Althusser's Marxist theory of ideology (1977) is one of the discourse analysts he uses. So are Bakhtin and Kristeva (Fairclough 1995a: 189). Fairclough regards his approach as 'critical' because it combines a Marxist theory of discourse with linguistic methods of text analysis. In Fairclough's work however, text analysis itself in 
its current forms came in for critique and considerable rewriting. He was as critical of some forms of text linguistics (1992; 1995a) as I and others have been of the research vocabulary of cultural studies above. In particular, rather as I have talked above of the nominalisation of categories like discourse, intertextuality and so on, he argues for the need to unpack categories like 'scripts' and 'frames', which as he says involve very little linguistic analysis. In most cases, he suggests, textual analysis is 'neither systematic nor detailed' (1992: 196) and intertextual analysis is rare. There is an implication here that discourse analysis should involve the two things, analysis of texture and intertextuality, and that no discourse (language in use in social process, language as action) can be understood except in relation to the larger discursive formations - orders of discourse - of which it is a part. That approach is the result, in Fairclough's work (e.g., 1995a )of bringing linguistics and language theory together with Foucault's theory of discourse and it signals as it did elsewhere when these approaches came together (Threadgold 1997) a new interest in understanding not just the workings of individual texts, but the ways in which they are traversed by traces of, and enter into networks of, other texts and discourses to form part of the hegemonic discursive structures which form social realities, subjectivities and bodies. That kind of work remains relatively rare in CDA and in cultural studies and yet, arguably, if Foucault's work on discourse had been really understood, work of this kind should have followed.

Fairclough's (1995 b, 112 ff., 183 ff.) work on discourse and intertextuality was the first in CDA in the UK to actually attempt a linguistic description of the poststructuralist categories of intertextuality and discourse. He chose the functionalist linguistics of Halliday (1985) for the analysis of 'texture', the structure and organisation of texts, but saw intertextual analysis rather than Halliday's original theory of the social semiotic (1978) as a crucial way of linking texts and contexts. He includes in the analysis of texture structures beyond the sentence (Halliday and Hasan's cohesion) and conversational analysis (Fairclough1995a: 188). Importantly for some of the arguments I have made earlier in this paper, he is concerned to argue that intertextual analysis is one of the ways in which social scientists might be persuaded to see the relevance of CDA to the kinds of work they want to do on larger social structures.

However, he does offer a caveat here. In my work with Kress (1988) intertextuality was identified with narratives, genres and discourses. These were seen as the categories of which intertextuality is constituted, categories which are realised linguistically in texts, and which in turn constitute the larger orders of discourse on which texts draw just as much as they draw on the resources of the linguistic system (see also Threadgold 1997, ch. 6). However, as Fairclough and others have pointed out, the recognition of these traces of orders of discourse in text is very much dependent on the analyst's experience, knowledge of the context of the text, and interpretative biases (Fairclough 1995: 212). This then requires that one 'engage in social and ethnographic research over significant periods of time in particular institutional settings' (Fairclough 1995: 212) in order to ground, and test, claims about intertextuality in and against more recognisable forms of social science research. I would add to this a comment that takes me back to my questions above about why certain kinds of textual work are characterised as empirical and other kinds as textual. If one is working with literary or 
philosophical texts, as Derrida for example does, the research that is required for justifying claims of intertextuality is wide reading in a textual field, 'dead texts' perhaps, but texts which, if we believe Bakhtin and Derrida, go on dialoguing in and with the present, go on being signed for in new contexts, go on constructing and forming worlds and people. My point here is that sometimes, in some fields of research, the materiality of the significant contexts with which one has to deal actually is constituted of other discursive (read here 'textual') events: although such events are always imbricated in materiality, especially for Derrida but for all poststructuralist theorists and for most proponents of CDA. Poststructuralist feminist work has, for example, argued that texts are always traces of bodies at work, that texts and bodies are always folded into one another (Threadgold 1997).

Teun van Dijk is among the best known and most influential of European critical discourse analysts and has recently produced two interesting text-book accounts of CDA (2001a; 2001b) which also identify other major European researchers in this field. Wodak's (2001) introduction to CDA provides another account of the development of the field and includes work from Germany not referred to in these other accounts. What is interesting about both these accounts is their difference from my own, and the questions both raise about CDA as any kind of established or clear-cut method for analysing texts or engaging in the typical politics that go with the field. Like van Dijk, Wodak points to the 'heterogeneity of methodological and theoretical approaches in this field' (2001: 2) and argues that what is common to different traditions is at best 'a shared perspective on doing linguistic, semiotic or discourse analysis' (2001: 2). Both trace the intellectual formation of the field back to Marx, the Frankfurt School and Habermas, Gramsci, Althusser, Foucault and Pecheux in different national contexts and van Dijk includes Stuart Hall and the Birmingham School of Cultural Studies as part of the narrative of the development of critical perspectives in the study of language (van Dijk 2001a: 301). Van Dijk is insistent on the anti-methodology stance we have seen earlier to be consistent with cultural studies and critical theory approaches. He argues that 'ready-made methods' are 'incompatible with a critical attitude' (2001b: 95). Nor, he says, is CDA a 'theory that can simply be applied to social problems' (2001b: 96). It is a 'perspective' on doing research which 'focuses on social problems' and 'on the role of discourse in the production and reproduction of power abuse or domination' (2001b: 96). His emphasis is on the necessity 'for a broad, diverse, multidisciplinary and problem-oriented CDA' (2001b: 97) which will select its methods and areas of analysis on the basis of a theoretical analysis of social issues (2001b: 98). His own example of 'how to do' CDA, his tool kit if you like, is distinctly different from the functional linguistic toolkits we have noted above. There are recognisable parallels in some of the areas of text and language explored but there is no common language here with Barker/Galasinski (2001), Fairclough or e.g., Kress/Threadgold.

These differences highlight some of the issues singled out by Wodak (2001: 12) as needing further research in the field: the problem of theorising the way texts mediate the relations between the social and the linguistic; which linguistic theory to apply (often 'a whole mixed bag of linguistic indicators and variables are used' with 'no theory of grammar' to support that use); the problem of defining 'context'; the accusation that the politics of CDA biases 
analyses; that the field has not yet achieved a real inter- or trans-disciplinarity. These questions are asked again by Wetherell (2001). They do not go away. Wetherell/Taylor/Yates (2001) have produced an Open University reader which attempts to construct the field as a field with methods in all of its diversity. It includes the following traditions: conversation analysis; discursive psychology; Foucauldian research; CDA and critical linguistics; interactional sociolinguistics and the ethnography of speaking; and Bakhtinian research. Wetherell too is in favour of 'the creative mixing of research questions and styles' (2001: 383) but points to the habits and the epistemological and methodological debates between different 'disciplines, domains and traditions' which often inhibits such creativity.

Among such resistances is one in particular which over the years I have not commented upon: the systematic failure of the key male figures in CDA with some exceptions (Teun van Dijk is one) to cite or use feminist work in the field. Women and men do work together. It is feminist theory which is resisted I think. A long time ago Meaghan Morris pointed to this same feature as a characteristic of early work in postmodernism and produced a whole bibliography of work by women in the field to challenge the typically masculine representation of it (1988). This absence in CDA may well impact on its reception in cultural studies where feminist theory has been strong.

These I think are very real issues which raise again the question of what value CDA might be to cultural studies. In a sense before we can ask that question we need to know: whether they are not already part of the same enterprise; what exactly it is that we are offering as CDA; whether CDA might still have things to learn from cultural studies and other places; whether the only thing we can really offer, 'a shared perspective' on doing the political work of CDA is not already shared with, and even derived from, encounters with poststructuralist and critical theory and cultural studies itself; and finally, what disciplinary and interdisciplinary resistances there may still be to change and innovation in research styles and methods, not only in cultural studies but in CDA itself.

\section{$5 \quad$ Intertextuality: Why Discourse, Narrative and Genre?}

It will be noticeable that the focus on intertextuality and discourse which I pointed to in Fairclough's work and my own above does not figure in the accounts by van Dijk and Wodak, (it does figure in Wetherell et al. (2001)) although they are both also concerned with the complex relations between linguistic and social forms (the macro/micro debate) which intertextuality tries to theorise. I want to return here to my earlier point about forgotten histories and try to rethink what we gain and lose by moving back and forth between different theoretical and disciplinary domains.

In my own feminist work, I have argued that what 'mediates' between textual forms and the social has to be the embodied subject. It is such subjects who, in negotiation with textual processes, make and remake themselves and the social. The body is marked and branded by these histories of material engagements with texts, carries the histories with it, and provides the resources for the performance of textuality in everyday life and social contexts (Threadgold 1997: p.97 ff.). What is in the body, inscribed on the body, lived through the 
body as institution and the social made flesh (Bourdieu 1990: 57), cannot be contained by any given context (Threadgold 1997: 101). Until we theorise the body in the ways that Bourdieu and feminist theorists have done, we will continue to have trouble understanding and theorising texts and contexts.

What is 'in the body' has been theorised in CDA, often only insofar as it leaves traces and marks in texts, and identified as the 'resources' subjects used to make texts with. Thus we have 'accumulated cultural and economic capital', habitus, (Bourdieu 1990), 'members' resources (Fairclough 1989), 'linguistic potential' (Halliday 1978), intertextuality and interdiscursivity (Bakhtin 1981; Kristeva 1970; Pecheux 1982). Bakhtin, Kristeva and Bourdieu all deal explicitly with the body and with exchanges between networks of bodies and texts, but in general the terms have been appropriated to describe and theorise relations between texts, again eliding the body and the material.

In a good deal of poststructuralist work the categories of genre (Derrida 1980), narrative (Lyotard 1984), discourse (Foucault 1973), myth (Barthes 1973) and metaphor (Ricoeur 1978) have also been privileged as constituting some combination of the resources subjects use to make texts with. These are resources derived from experience on and with other texts, large chunks of pre-processed reality, ready-made text to use again as the occasion arises. The references I have just given are at least the source of my own use of this terminology. The terms along with 'subjectivity', 'intertextuality' and 'performativity' have become part of the poststructuralist metalanguage I discussed above and also part, as we have seen, of that of some forms of CDA. They do not any longer however 'mean' the same things in these different places.

Fairclough uses intertextuality, discourse and genre to analyse a text's relations with other texts in the orders of discourse of which it is a part in a very Foucauldian move. I used them to do that too but also to think about subjectivity and embodied experience as these things leave corporeal traces in texts: the 'I' of the enonciation and the 'I' of the enonce (Benveniste 1966), the subject who writes/speaks and the subject who is written/spoken (Barthes 1986; Kristeva 1980). Foucault's concern, in his early work at least, is always with the positioned, disciplined subject. He has relatively little to say about the 'I' who speaks, self-consciously and intentionally. I have also explained this as being about the difference between the agentive subject who produces a well-formed generic text as opposed to the subject positioned/constructed in discourses and genres (and in my work also narratives) which are incorporated unconsciously (much as the system of language is used without conscious articulation of a metalanguage) into the texts s/he produces and which traverse the wellformed generic structure of those texts vertically and in ways which do not map easily onto the kinds of structures linguistic modes of analysis identify.

The 'I' of a specific genre occupies a different position to the subject spoken in the discursive statements that may traverse her speaking. The first 'I', equally constructed and produced in language, nevertheless knows what it does, and assumes a position as knower which does not recognise itself as 'a subject in process', split between the conscious and the unconscious (Kristeva 1980: 19). 
Kristeva's use of 'intertextuality' came from her reading of Bakhtin on heteroglossia and dialogism and she uses it to describe the transposition of one or more systems of signs into another with always a difference in enunciative and denotative positionality. Her examples are of the transposition of the sign systems of courtly love, carnival and scholastic discourse into the novel. She was exploring a genre which was the hybridisation of several earlier genres or modes of utterance and her analysis involved locating the transformations of these sign systems within the text of a single novel (Kristeva 1979). Bakhtin had argued (1986) not only that the word 'discourse' always carries with it the histories of where it has been before but that genres and the intertextual fragments they embed are always in a dialogic relation, so that there is the potential for constant recontexualisation and resignification. Importantly, in this work, intertextuality was as much about how to make texts as how to analyse them. Speakers make texts chunk by chunk as well as word by word and there are many systems they use as resources, not just the linguistic system. Rossi-Landi (1977) is the only linguist I know who has begun to theorise this.

As the terms of this metalanguage are adopted in new and different contexts it is precisely a process of Bakhtinian recontextualisation and resignification that we see at work. In the use of intertextuality in both cultural studies and CDA, the word cannot be relied upon, contra Bakhtin, to bring all of its histories with it: and the partial histories dialogue with new contexts and become transformed again. Much of cultural studies and CDA compares quite easily with Kristeva's hybrid genre. Thus the use of the word often conflates or confuses Foucault's understandings of the way discourses circulate in networks of texts, the complex interdiscursive relations between the discursive and the non-discursive in Foucault's work, with Bakhtinian notions of heteroglossia and dialogism derived from Kristeva and Barthes and the additional terms citation and iterability derived from Derrida and others. There is a mix here of an early Marxist theory of language (Bakhtin), an anti-representational, antisemiotic discourse (Foucault), a psychoanalytic semiotics (Kristeva) and a philosophical discourse on language (Derrida and Butler). This may not matter if the definitions and uses in the new contexts are clear, but it does suggest that there is still a good deal to learn from the work that provided the terms of the metalanguage in the first place and that forms of CDA have to date engaged with a very small part of the richness that is there to be explored.

Moreover, it seems to me that we need a lot more research on intertextuality. The metalanguage that I developed for talking about it was derived intertextually from the texts of critical theory, borrowed from there intertextually into the work of Kress/Threadgold (1988) and then again into Fairclough's work. We all made it work on other texts to theorise how they functioned in networks of other texts but we did not go looking for other kinds of intertextuality than those already projected into our research by the histories our metalanguage brought with it. There is for example still work to be done on exploring the connections between the cognitive discourse of 'frames' and 'scripts' and the intertextual categories used above. There is work to be done on citations in texts which are attributed and therefore not unconscious in their use. Derrida's texts are full of such citations. So is every academic literature review and every academic paper of the kind I am writing now. We do know that this is part of the way in which subjects are disciplined. apprenticed in an academic 
field, but we talk less about this as a way in which subjects are unconsciously positioned as well. The relationship between intertextuality and plagiarism is ripe for investigation as well: somehow if the chunks of text we make texts with are part of the 'murmur of the culture', oral, unauthored or at least with no named author, that is not to steal words. The speech/writing binary is at work here too. The minute the chunk comes from an identifiable written text there has been a robbery. What is the difference between intertextuality as citation and quotation and projection of the kinds recognised in linguists' grammars? What of dialogues between texts? I described one such dialogic process in which texts take up from where others leave off over many years in chain of interactions moving from media discourse to documentary to novel to film and so on (Threadgold 1997). The way in which journalistic news texts interact and dialogue would be another example. We have not really researched that as a key part of the ways in which meanings are made. There may be a new role for conversational analysis here. And if texts and bodies do fold into one another, if the body and the subject mediate the relationship between text and context, how do we research that?

\section{$6 \quad$ Foucault and Discourse}

Another problem it seems to me is that in recognising the need to identify the linguistic realisations of intertextuality in verbal texts, we have been less brave in making the next step and learning how to link the traces we thus identify with orders of discourse which are not specifically verbal. Foucault's work on discourse insisted that orders of discourse, assemblages or mechanisms, are what Deleuze would later describe as 'mushy mixtures of the visible and the articulable' (Deleuze 1986: 38). In Discipline and Punish, as Deleuze points out (1986:33) Foucault raises the two problems that could not be raised while the statement remained tied to knowledge and to discourse (see Threadgold 2000) as it did in The Archaeology of Knowledge and tends to do in CDA and Cultural Studies. Between penal law as a formation of statements, a form of expression, which articulates criminality, and the prison, a new way of acting on bodies, a form of content which has its own statements and regulations, but is concerned with whatever is visible, a visual assemblage, both defined by 'Panopticism', there is a mutual presupposition, but 'how do the assemblages, adjustments and interpenetrations of the two forms come about?' (Deleuze 1986: 33). Foucault calls the immanent cause of this coming together a diagram or a cartography, an abstract machine that makes no distinction between 'content and expression, a discursive formation and a nondiscursive formation' (Deleuze 1986: 34). The example of a diagram is 'modern disciplinary societies where power controls the whole field' (Deleuze 1986: 34), the diagram is 'like the cause of the concrete assemblages that execute its relations' (Deleuze 1986: 37). In the case of the prison and the penal law it is panopticism which diagrams the assemblage and is produced as relations of force within the very assemblages which it maps.

It is not a relationship of form and content, expression and meaning: the prison is not the visible and silent content, meaning, of the audible form/expression that is the penal law. The language and the context, if you like, are not isomorphic as they were, for example, in Halliday's theory of social semiotic. Rather, as Deleuze has explained, drawing on Hjelmslev's more complex understanding of the content and expression planes of language 
(1986: 47), both the form and the content have a form and a substance: the prison as content has a form, the prison architecture, and a substance, the prisoners, while the penal law as expression has a discursive form which produces the substance delinquency. The relations between the two lie in their heterogeneous realisations of optical and panoptical procedures, the relations of power which diagram, map their functions and institutional force. The 'encounters' between what linguistics might have called a form and a content, the fact that they may appear to co-adapt, are a function of the multiple 'dependencies' that may exist within a discursive field, not the result of a semantics.

There is a good deal of excellent work which has taken these more complex understandings of Foucault as its framework. There is no attempt to be exhaustive in the few examples that follow. Carmen Luke's remarkable book Pedagogy, Printing and Protestantism: The Discourse on Childhood (1989) is one example which takes into account and explores the complexities in Foucault's own work. Hunter's (1988) Culture and Government: The Emergence of Literary Education and his essay 'Aesthetics and Cultural Studies' (1992) emerge from close engagement with the early and late Foucault respectively. None of these uses any form of critical discourse analysis to do its work. Dorothy Smith in her Texts, Facts and Femininity (1990) is another who understands Foucault, although her understandings are certainly not limited to his work: 'Analysis focuses on ... how the reader operates the text to enter the objectified modes of knowing characteristic of the relations of ruling. ... The focus of enquiry is the textually vested versions of the word that are constituents of the relations of ruling.' (1989: 5f.). Smith's work is informed by ethnomethodology, Marx, conversational analysis and poststructuralist forms of discourse analysis. It attempts to rewrite sociology from the perspective of the embodied subject, with an insider's knowledge 'of the social organisation of the actual practices that bring actualities of society into being' (1989: 10). Here is a feminist sociologist who understands what Foucault had to offer and makes her own located use of that work. She does not use a recognisable methodology as such but an eclectic and very efficient method which has connections with much good work in CDA of a similarly eclectic kind.

In CDA itself, the attempt to think and theorise relations between semiotic systems, or to theorise 'multi-modal' discourse becomes more common but is still regularly more dependent on semiotics and on understandings of language as social semiotic than it is on Foucault's work or on theories of the body. This is not a criticism but it does mean that Foucault's particular take on these things has not yet been fully explored in CDA. The work of Kress/van Leeuwen (1996), of van Leeuwen (1999): and Kress/van Leeuwen (2001) is the most significant in the CDA field itself. My own work on performance (1997: 118-133; 2002) is shaped rather differently because of my focus on the body and the making of the embodied performance text in rehearsal. Fairclough (1995b: chs. 4 and 5) in exploring media texts presents a case for discourse as realised in many different semiotic forms, for analysing texts/orders of discourse, and for analysing discourse practice, the practices of production and consumption, in this case, of media texts. There are parallels here with my own account above of my uses of intertextuality, but the languages are very different. However this account does reflect some of Foucault's complexity. This is again a very different kind of analysis to 
Threadgold (1997: chs. 7 and 8) which attempted to track a discourse of race across a hundred years of Australian history in the transformations and transpositions of a single narrative in everyday talk, media representations, legal practice, literature, literacy classrooms, tourism and film. In one sense what I was then trying to do was to show how 'race', and the relations of power inherent in that, diagrammed this complex assemblage of practices and texts, how it mapped their functions and institutional force, how hugely stable the assemblage was and how resistant to the attempts to rewrite it in non-racist ways. This still forces me to ask whether 'making visible' and 'rewriting the story' can be a sufficient politics for either CDA or for poststructuralist discourse analysis. And much as they share a politics, it seems to me they also share this problem, of still not engaging sufficiently with the materiality of bodies and worlds. This returns us to Wodak's question about what mediates text/context relations and how much context to include and how in CDA? I will return here to the terms citation, iterability and performativity as currently used in cultural studies and many other places including Barker/Galasinski (2001) at the beginning of this paper to explain what I mean.

\section{$7 \quad$ Performativity}

The term performativity has recently come to be used in a wide range of contexts to refer to what might earlier have been referred to as the performance of the self. In its current uses however the term refers specifically to a gendered, and sometimes a raced, classed or ethnic performance of the self, and it connotes feminist work on the body and embodied subjectivity as well as carrying the implication that such a self is socially constructed and might therefore be constructed differently. As it is currently understood, performativity is derived most directly from the work of feminist scholar Judith Butler, where one of the central concerns was to understand the relationship between speech and act, act and identity, and specifically to understand how the connections between certain acts and certain forms of speech, habitually enacted together, come to constitute a compulsory performance (an embodiment) of heterosexuality. The relationship between performativity and performance, somewhat blurred in the formulations above, is also in need of clarification. Performativity in Butler's work derives from the work of J.L Austin (1976) and is a philosophical/linguistic concept. Performance is primarily a theatrical (Parker/Sedgewick 1995) term but one which has been used and useful in sociology and anthropology to describe the 'performance' of everyday life as well as the enactment of ritual, ceremony and so on (Schechner 1985; Turner 1987). Clarification of the relations between these terms requires some history and some investigation which goes back a long way before Judith Butler's work made the term performativity so popular in cultural studies.

\section{J.L Austin (1955/1976) How to do Things with Words.}

Austin's work belongs in the tradition of 'ordinary language' philosophy, a tradition whose intellectual consequences we now take so much for granted that we rarely remember what the issues were which exercised it. The lectures Austin gave at Harvard in 1955 in which he developed his theory of the speech act and the performative were concerned with challenging existing philosophical positions concerning language and its functions: the assumption that 
language consisted of statements, which 'referred' to something, and were always either true or false. For Austin, this was demonstrably not the case and he chose a number of statements (he called them constatives) which seemed to 'masquerade as a statement of fact' (1955: 4) but were in fact neither describing nor reporting anything, not true or false, but were utterances which involved 'the doing of an action':

'I do (sc. take this woman to be my lawful wedded wife)'- as uttered in the course of the marriage ceremony.

'I name this ship the Queen Elizabeth' - as uttered when smashing the bottle against the stern.

'I give and bequeath my watch to my brother' - as occurring in a will.

(Austin 1955: 5)

These were the kinds of utterances which Austin called performative. It is worth noting that in each of the examples above, Austin provides a context in which the performative speech act would be appropriate and would successfully accomplish the action it performs. He went on to describe what he called 'the doctrine of infelicities' (1955: 14) in which he attempted to account for all the kinds of things which might go wrong and mean that a performative speech act did not work as it should. For example one might say: 'I take this man to be my wedded husband' in a context which was not that of marriage, and addressed to someone without the power to enact that marriage. In such a case the performative would be 'infelicitous'. The case of infelicity for which he has been remembered best, because of Derrida's later challenge to it (but there were many others), was that which involved precisely the theatrical, or literary, performance of an otherwise performative speech act:

... a performative utterance will, for example, be in a peculiar way hollow or void if said by an actor on the stage, or if introduced in a poem, or spoken in soliloquy. ... Language is such circumstances is in special ways - intelligibly - used not seriously, but in ways parasitic upon its normal use - ways which fall under the doctrine of the etiolation of language. (Austin 1955:

At first Austin distinguished performatives very strictly from statements or constatives but as he worked more on and with them, he began to understand that this distinction really would not hold. He believed for a time that the distinction 'performative-constative' might be justified as a distinction between 'doing and saying' (1955: 47), but the more he attempted to find grammatical criteria to define the performative, the more he became convinced that 'it is often not easy to be sure that, even when it is in explicit form, an utterance is performative or that it is not.' (1955: 91) By 'explicit' he meant those utterances in the first person singular present indicative active which he had first characterised as bearing the mark of the person uttering and enacting the performative: e.g., I apologise, I criticise, I approve.

This was the point at which he developed the terminology locution, illocution, perlocution. A locutionary act is a simple use of speech to mean or to refer, but such a use always has illocutionary force, that is it does something like making a statement, asking a question, giving an order. At the same time, it may also perform an act of another kind, it may 'produce certain consequential effects upon the feelings, thoughts or actions of the audience, or of the speaker, or of other persons: and it may be done with the design, intention, or purpose of producing them.'(Austin 1955: 101) In this sense then, Austin saw that all ordinary language 
speech acts were performatives and that any speech act usually functioned to perform several kinds of act at once: referring/meaning, stating/asking etc., persuading/intending and so on.

\section{$9 \quad$ Derrida and Austin}

Derrida's (1982) account in 'Signature, Event, Context' of the 'relative originality' of Austin's (1955/1976) theory of the speech act focussed on the fact that Austin did not see communication as being about 'the transport or passage of a content or meaning' but rather saw it as an event, as being about 'the production of an effect', 'the performative .... would be to communicate a force by the impetus of a mark' (Derrida 1982: 321).

Austin was, for Derrida, radical in 'exploding' the traditional concept of communication by recognising the conventionality of the contexts in which statements were made but less so, Derrida argues, in failing to recognise the 'intrinsic conventionality of locution itself' (1982: 323). This was the circumstance which impelled Derrida to theorise iterativity, to place the focus firmly back on the structure and form of the utterance itself. Iteration, in Derrida's work, deconstructed the opposition between repetition and difference, between stasis and change, indicating that repetition always involved a certain instability, that although convention and repetition are fundamental to communication, nothing is ever repeated in exactly the same way.

This was because what was crucial to understand for Derrida was not that the locution would be infelicitous if the context did not remain the same, but rather that the locution would go on meaning in radical disregard of the proper or appropriate context. Because of this radical structure of the mark, of writing (which in Derrida includes the speech act) there can be no 'infelicities' in Austin's sense - 'Every sign., linguistic or non-linguistic, spoken or written (in the usual sense of this opposition) ... can be cited ... thereby it can break with every given context, and engender infinitely new contexts in an absolutely unsaturable fashion.' (Derrida 1982: 320). The citation of the mark, that is the repetition of the conventional locution, is what is called iterability. The fact that the mark/locution can be cited (and made to signify) in any context at all is what ensures instability and change. Note the parallels here with Bakhtin's understanding of dialogism. This concept of citation and iterability is central to Judith Butler's understanding of the way change in meaning, what she calls resignification, and later, a different performance of the self, takes place.

\section{Judith Butler}

Judith Butler's work has been in every sense a feminist politics of the body. She has argued that it is the speech act as performative which both materialises and makes bodies matter (Bodies that Matter 1993). Her work has challenged the hegemony (the compulsory performance of heterosexuality) which banishes certain ('lacking'/deficient - e.g., women's, racialised, gay and lesbian) bodies to an abject and excluded realm, the realm of matter or nature. Butler is working here with Irigarayan ideas, specifically the notion that radical alterity (woman) has always been associated with the 'outside of language', the inarticulable, 
nature/matter. Butler's work and her politics are aimed at forcing 'a radical rearticulation of what qualifies as bodies that matter' (1993: 16).

Butler's account of performatively enacting social change involves recognising on the one hand, the power of the speech act as citation and iteration (being repeated in the same conventional forms) to produce stable hegemonies (e.g., heterosexuality as norm) and on the other, understanding that the very business of iteration, in its interaction with new contexts, produces the possibility of change. In her work the term iteration, like citation, is further complicated by being read through psychoanalysis. Thus she asks: 'Is "assuming" a sex like a speech act?' (1993: 108) Her answer is that it is never a single act, but is rather 'an iterable practice'. Assuming a sexed position involves, according to Lacan, obeying a legislative norm, but to do that involves/requires 'citing or miming that norm' repeatedly. It is in that repetition/iteration, in Butler's work, that both the power of the law and the possibility of recognising it for what it is and refusing it is to be found.

Thus Butler 'makes visible' the gender hierarchy and its performative mode of production, linking speech act to body through her understandings of Althusser's concept of the materiality of ideology (it is bodily practice which makes us believe) and Foucault's work on the disciplining of the body through the practice of discursive events. 'Gender is the repeated stylization of the body, a set of repeated acts within a highly rigid regulatory frame that congeals over time to produce the appearance or substance of a natural sort of being' (Butler 1990: 33). Butler does also attempt to understand how norms of gender, sexuality and race intertwine in the production of different kinds of subjects.

However, the question we have to ask is whether 'making visible' what iteration does and then recontextualising so as to 'resignify' the processes of iteration of gender norms, is actually enough to effect a change, to radically alter the system of gender hierarchy, compulsory heterosexuality and other forms of oppression. Butler's work, despite being about the body is in fact textual and it works on and with texts to change the meanings of heterosexuality and its others: e.g., the reading of alternative kinship structures in the film, Paris is Burning, as a resignification that 'might help to rethink the terms that establish and sustain bodies that matter' (1993: 240f.). The question however of what an 'affirmative resignification' might be remains open since 'the one who utters or writes' cannot control the effects of performatives, which 'continue to signify in spite of their authors, and sometimes against their author's most precious intentions' (1993: 241). For Butler this not knowing, 'the incalculable effects of action', results from always being implicated in what one opposes while trying to turn power against itself (1993: 241).

Kirby (1997) has argued that Butler's account is limited to a linguistic or discursive account which fails to understand the way oppression may actually craft and shape the materiality of the body through, for example, starvation, torture, long hours of lowly paid and exploited labour and so on. Similarly Pheng Cheah (1994: 138f.) has questioned the metaphor of rewriting, resignification, asking whether it constitutes an adequate model of agency in a neocolonialist space where the very matter of the body 'bears the instituted trace of the spacing and timing of imperialism'. In such a space: 
Inscription will unfortunately exceed the undoubtedly important horizons of sexual preference and the choice to cross-dress or engage in sadomasochistic sex. Because we would here have to consider embodiment at the mundane level of food production, consumption and superexploitation outside wage labour, the concept metaphor of inscription will have to be rethought as habitation. ... oppression occurs in the very crafting of the materiality of our bodies. (Pheng Cheah 1994: 138f.)

For Pheng Cheah this body of the other cannot be accommodated within an academic feminism informed by the 'whiteness', the linguisticism and the privilege of the psychoanalytical and poststructuralist narrative.

This is why it has been suggested that performance (Parker/Sedgewick 1995; Threadgold 1997), grounded in its theatrical senses, where it will not allow the elisions of the body that performativity permits, may need to be brought together with performativity in trying to deal with the complex ways in which bodies and texts fold into one another, crafting and shaping the materiality of texts and of bodies. To perform in theatre contexts, or indeed in the contexts of everyday life, for which theatre here becomes a metaphor, is always to struggle with the substance, the matter, of the body. Ethnographies of theatrical rehearsal offer one place for doing fieldwork on the way repeated acts congeal over time to produce a disciplined performance of the body, a believable habitus (Threadgold 1997). To remember that may remind us of the 'parasitic' presence of the theatre in Austin's work. It certainly points to the difficulties and the unresolved issues in Butler's work despite the readiness with which the term performativity has been co-opted in cultural studies, CDA and elsewhere.

\section{Conclusions}

In a sense then we are back with Barker/Galasinski's (2001) argument that we need empirical work to test the metaphors and narratives of critical theory. However we do not just need to rethink talk as text rather than evidence. We also need to think of it as embodied, located in space/time, tied into institutional and community practices and knowledges, dialoguing with other textual practices, mediating power relations and the relations of ruling, calling out for ethnography as well as CDA and maybe needing to be analysed in quantitative as well as qualitative ways.

The work of Luke (1992) and of Kamler et al (1994) is exemplary of ways in which Bourdieu's notion of the habitus: 'as political mythology realised, embodied, turned into a permanent disposition, a durable way of standing, speaking, walking and thereby of feeling and thinking' - can be used along with Foucault and critical linguistics/discourse analysis to explore in an ethnographic setting the issues that concerned Butler. They use these tools to carefully observe and analyse the processes (linguistic, corporeal, spatial, visual and etc.) by which the bodies of little girls and boys become gendered in early literacy classrooms. The critical factor here is that the reiteration of gender norms is able to be specified and analysed and modes of intervention can therefore be planned to effect change. We do not have to rely on the vagaries of iteration or on texts wandering about on their own looking for signatures. 
Versions of CDA (and I define this here in the way van Dijk does above as a set of creative potentials for working with, not a fixed method) in contexts like this make it possible to see what is happening at a level of detail that the poststructuralist categories cannot accomplish because of the levels of abstraction at which they work. CDA is also entirely compatible with ethnographic work in the places where the habitus is being formed. Detailed work on and with linguistic and textual structure actually produces agency for the researcher. Understanding the minutely detailed ways in which bodies are crafted and learn to perform can clarify the sites for intervention and even begin to predict the effects of political action. Of course the Derridean critique also holds good: the unexpected and the unpredictable may happen, but then the detail provides other alternatives for new kinds of action.

In addition, linguistic work on the poststructuralist categories, of the kind we have explored above certainly shows the effects of iterability, but makes them also subject to intervention and political action. If for example, intertextual categories are always used 'whole', unanalysed, as they tend to be in certain kinds of analyses - 'here there is a discourse of race', 'there a genre embedded in another genre' - they can only be described and identified. Analyse them in fine detail, figure out how they work, think about how they are institutionally supported and reproduced and what effects they have on bodies, on the organisation of space and social interaction, for example, and you begin to have some tools for intervening at the most unconsciously articulated levels of text. These are where the huge stabilities of discourse are hardest to unsettle. You also begin to understand the narratives, discourses and myths which form the habitus. In fact iterativity and citation, as defined by Derrida and Butler, seem to provide some of the best arguments there are for using forms of critical discourse analysis in cultural studies work. However, it seems to me that the best work will constantly bring new theories and new readings of old ones together with the doing of critical linguistic work. It is only when such work is constantly informed by and challenged by difficult theory that it will continue to be creative and productive.

In what I have discussed above here are many different kinds of critical reading practices, using many different tools and languages. We might call them different genres of reading. Critical discourse analysis cannot do all the things all these different kinds of practice - and many others we have not discussed - can contribute. CDA shares a politics with most of these practices. They can be brought together constructively or we may just have to allow that there is more than one form of critical reading practice, analysis, which can intervene in social practices to produce social change in the ways in which it is claimed that CDA can do. We must acknowledge the centrality of the embodied subject and the need to theorise, and find ways of changing, bodies, social geographies, practices as well as texts. I would like to see students and scholars able to use as many modes of critical reading as possible. But I would like to see them used from long and serious engagement with the primary texts of disciplines like sociology, anthropology, history, geography and the critical theories and traditions which inform them and shape them, not from anthologised and necessarily reduced versions. I would like to see this happen in cultural studies and in critical discourse analysis. If it did, CDA would certainly evolve and change some more and so would cultural studies. I have always 
argued that the more places you have from which to look, the more you are likely to see and the more you are likely to unsettle the habits of your own corporeal ways of knowing.

We might for example even move beyond the very Western traditions of knowledge I have just named and begin to learn from cultural and other differences in our midst to produce new versions of CDA that really acknowledge the difference of those to whom we teach it and those whose oppression is the subject of our labours. What does it help an asylum seeker that I perform an intelligent and politically committed analysis of her discourse? It will only help if I can use it to influence policies which determine the material conditions of asylum seeking. What if Kirby (1997) is right and the materiality of the body at the scene of writing is itself articulate, if biology can speak and write? Perhaps then the most radical kind of critical discourse analysis would involve teaching people that their biology, the habituated body, can write and speak, that they can write and speak themselves differently, and providing the training, the spaces and the opportunities for them to do that. Sometimes though it is the right to food and water that matters most, that crafts and shapes the body more potently than any writing.

The politics of writing, writing the body, critical discourse analysis and cultural studies, all of these are different to politics which intervene in corporeal and othered spaces, but as Butler's and others' struggles with language and discourse show, they can never be entirely separate. That is why we must do more work on the relationships between the two, more work on understanding how much context matters, more work on making the languages in which we do it accessible to those who need them, and more work on learning how to see the world from other places than the privileged ones we tend to occupy. Only then will the worlds we inhabit change our theories and methods to the point where they may actually produce the social change they theorise and to which they make claim.

\section{References}

Althusser, Louis (1977): Lenin and Philosophy and other Essays. Surrey.

Ang, Ien (1996): LivingRoom Wars: Rethinking Media Audiences for a Postmodern World. London.

Austin, John L. (1976): How to do Things with Words. Edited by Jo Urmson and Marina Sbisà. London/Oxford/New York.

Axelrod, Rise B./Cooper, Charles R. (1993): Reading critically, Writing Well: A Reader and Guide. Third edition. New York.

Bakhtin, Mikhail (1981): The Dialogic imagination: Four Essays by M.M. Bakhtin. Edited by Michael Holquist. Austin.

Bakhtin, Mikhail. (1986): Speech Genres and Other Late Essays. Edited by Cary Emerson and Michael Holquist. Austin.

Baker, Houston A. Jr./Diawara, Manthia/Lindeborg, Ruth H. (eds.) (1996): Black British Cultural Studies: A Reader. Chicago/London.

Barker, Chris/Galasinski, Dariusz (2001) Cultural Studies and Discourse Analysis: A Dialogue on Language and Identity. London. 
Barthes, Roland (1953/1967): Writing Degree Zero. New York.

Barthes, Roland (1964/1967): Elements of Semiology. New York.

Barthes, Roland (1986): "To Write: An Intransitive Verb?". In: Barthes, Roland (1986): The Rustle of Language. Oxford: 11-21.

Bennett, David (ed.) (1993): Cultural Studies: Pluralism and Theory. Dept. of English, University of Melbourne, Victoria.

Bennett, Tony (1998): Culture: A Reformer's Science. Sydney.

Benveniste, Emile (1966): Problemes de Linguistique Generale. Paris.

Birch, David/O'Toole, Michael (eds.) (1988): Functions of Style. London.

Bourdieu, Pierre (1990): The Logic of Practice. Cambridge.

Butler, Judith (1990): Gender Trouble: Feminism and the Subversion of Identity. New York/ London.

Butler, Judith (1993): Bodies that Matter: On the Discursive Limits of "Sex". New York/London.

Cameron, Deborah (2001): Working with Spoken Discourse. London.

Clifford, James/Marcus, George (eds.) (1986): Writing Culture. Berkeley.

Curran, James (1996): "The New Revisionism in Mass Communication Research: A Reappraisal". In: Curran, James/Morley, David/Walkerdine, Valerie (eds.): Cultural Studies and Communications. London: 251-278.

Curran, James/Morley, David/Walkerdine, Valerie (eds.) (1996): Cultural Studies and Communications. London.

Deleuze, Gilles (1986/1988): Foucault. Translated and edited by Sean Hand. Minneapolis.

Derrida, Jacques (1967/77): Of Grammatology. Baltimore/London.

Derrida, Jacques (1972/1982): "Signature, Event. Context". Translated by Alan Bass. In: Derrida, Jacques: Margins of Philosophy. Chicago: 307-330.

Derrida, Jacques (1978/1981): "Structure, Sign and Play in the Discourse of the Human Sciences". Translated by Alan Bass. In: Derrida, Jacques: Writing and Difference. London/Henley: 278-294.

Derrida, Jacques (1988): Limited Inc. Evanston, III.

Derrida, Jacques (2002): Negotiations: Interventions and interviews 1971-2001. Stanford/ California.

van Dijk, Teun (2001a): "Multidisciplinary CDA: a plea for diversity". In: Wodak, Ruth/ Meyer, Michael (eds.): Methods of Critical Discourse Analysis. London: 95-120.

van Dijk, Teun (2001b): "Principles of Critical Discourse Analysis". In: Wetherell, Margaret et. al. (eds.): Discourse theory and Practice: A Reader. London: 300-317.

Durram, Meenakshi/Kellner, Ddouglas M. (eds.) (2001): Media and Cultural Studies: Keyworks. Oxford.

Eco, Umberto (1979): A Theory of Semiotics. Bloomington.

Eldridge, John (ed.) (1993): Getting the Message: News, Truth and Power. London.

Fairclough, Norman (1989): Language and Power. Essex, UK.

Fairclough, Norman (1992): "Discourse and Text: Linguistic and Intertextual Analysis within Discourse Analysis". Discourse and Society, Vol. 3, No. 2.: 193-217.

Fairclough, Norman (1995a): Critical Discourse Analysis. London/New York. 
Fairclough, Norman (1995b): Media Discourse. London.

Foucault, Michel (1975/1982): Discipline and Punish: The Birth of the Prison. Harmondswoth.

Foucault, Michel (1966/1973): The Order of things: An Archaeology of the Human Sciences. New York.

Foucault, Michel (1969/1972): The Archaeology of Knowledge. London.

Fowler, Roger (1981): Literature as Social Discourse: The Practice of linguistic Criticism. Bloomington.

Fowler, Roger/Hodge, Robert/Kress, Gunther/Trew, Tony (1979): Language and Control. London.

Gordon, Avery F. (1997): Ghostly Matters: Haunting and the Sociological Imagination. Minneapolis/London.

Gray, Anne/McGuigan, Jim (eds.) (1993): Studying Culture: An Introductory Reader. London.

Grossberg, Larry/Nelson, Cary/Treichler, Paula (eds.) (1992): Cultural Studies. New York/London.

Hall, Stuart (1996): Critical Dialogues in Cultural Studies. edited by David Morley and Kuan-Hsing Chen. London.

Halliday, Michael/Hasan, Ruquaya (1976): Cohesion in English. London.

Halliday, Michael (1978): Language as Social Semiotic: The Social Interpretation of Language and Meaning. London.

Halliday, Michael (1985): An Introduction to Functional Grammar. London.

Hebdige, Dick (1979): Subculture: The Meaning of Style. London/New York.

Hodge, Robert/Kress, Gunther (1979/1993): Language as Ideology. Second edition. London.

Hunter, Ian (1988): Culture and Government: The Emergence of Literary Education. London.

Hunter, Ian (1992): "Aesthetics and Cultural Studies". In: Grossberg et. al. (eds.): Cultural Studies. New York/London: 347-372.

Johnson, Barbara (1981): J. Derrida Dissemination. Chicago.

Kamler, Barbara/Maclean, Rod/Reid, Jo-Anne/Simpson, Allan (1994): Shaping up Nicely: the formation of schoolgirls and schoolboys in the first month of school. A Report to the Gender Equity and Curriculum Reform Project, Department of Education, Employment and Training. Canberra/Geelong/Victoria.

Kirby, Vicki (1997): Telling Flesh: The Substance of the Corporeal. London/New York.

Kondo, Dorinne K. (1990): Crafting Selves. Chicago.

Kress, Gunther/van Leeuwen, Theo (1996): Reading Images: The Grammar of Visual Design. London.

Kress, Gunther/van Leeuwen, Theo (2001): Multimodal Discourse: The Modes and Media of Contemporary Communication. London.

Kress, Gunther/Threadgold, Terry (1988): "Towards a Social Theory of Genre". Southern Review, 21: 215-243.

Kristeva, Julia (1970): Le Texte du Roman. The Hague/Paris/New York.

Kristeva, Julia (1974/1984): Revolution in Poetic Language. New York.

Lacan, Jacques (1966/1982): Ecrits: A Selection. Translated by Alan Sheridan. Bristol. 
Lee, Alison/Poynton, Cate (eds.) 2000: Culture and Text: discourse and methodology in social research and cultural studies. Sydney.

Lowe, Lisa (1996): Immigrant Acts: On Asian American Cultural Politics. Durham/London.

Luke, Allen (1992): "The Body Literate: Discourse and Inscription in Early Literacy Training". Linguistics and Education 4: 107-129.

Luke, Allen (1997): "Shaping the Social Practices of reading". In: Muspratt, Sandy/Luke, Allen/Freebody, Peter (eds.): Constructing Critical Literacies. Creskill/NJ: 185-225.

Luke, Allen/Freebody, Peter/Gilbert, Pam (1992): "What counts as reading in the secondary classroom: the selective tradition of reading practices and positions." In: Christie, Frances et al. (eds.): Teaching English Literacy. Vol. 2. Canberra: 113-124.

Luke, Carmen (1989): Pedagogy, Printing and Protestantism: The Discourse on Childhood. Albany.

Lyotard, Jean-Francois (1979/1984): The Postmodern Condition: A Report on Knowledge. Manchester.

Meinhof, Ulrike H./Galasinski, Dariusz (2000): "Photography, memory and the construction of identities on the former East-West German Border". Discourse Studies, 2(3): 33233353.

McRobbie, Angela (1992): "Post-Marxism and Cultural Studies: A Postscript". In: Grossberg, Lawrence et. al. (eds.): Cultural Studies. New York/London: 719-730.

McRobbie, Angela (1994): Postmodernism and Popular Culture. London.

Miller, David/Kitzinger, Jenny/Williams, Kevin/Beharrell, Peter (1998): The Circuit of Mass Communication: Media Strategies, Representation, and Audience Reception in the AIDS Crisis. London.

Morris, Meaghan (1988): The Pirate's Fiancee: feminism reading Postmodernism. London.

Norris, Christopher (1992): Uncritical Theory: Postmodernism, Intellectuals and the Gulf War. Amherst.

Norris, Christopher (1993): The Truth About Postmodernism. Oxford.

Parker, Andrew/Sedgewick, Eve Kosofsky (1995): Performativity and Performance. London.

Pecheux, Michel (1982): Language, Semantics, Ideology. London.

Pheng, Cheah (1994): "Sexual Difference, Cultural Difference - Body and History in Gallop. In: Matthews, Julius (eds.): Jane Gallop Seminar Papers, Humanities research Centre, Monograph 7, Canberra: 47-71.

Philo, Greg (ed.) (1999): Message Received: Glasgow Media Group Research 1993-1998. London.

Poynton, Cate (1985): Language and Gender: Making the Difference. Oxford.

Poynton, Cate (1993): "Grammar, Language and the Social: poststructuralism and systemicfunctional linguistics". Social Semiotics 3, 1: 1-23.

Rice, Philip/Waugh, Patricia (eds.) (1989): Modern Literary Theory: A Reader. Third edition. London.

Rossi-Landi, Ferrucio (1973): Ideologies of Linguistic Relativity. In: Sebeok, T.A. (ed.): Approaches to Semiotics 4. The Hague.

Saldivar, Jose David (1997): Border Matters: Remapping Cultural Studies. Berkley. 
Sapir, Edward (1921): Language. New York.

de Saussure, Ferdinand (1959): Course in General Linguistics. Edited by Charles Bally and Albert Sechehaye. London.

Schechner, Robert (1985): Between Theatre and Anthropology. Philadelphia.

Schirato, Tony/Yell, Susan (1996): Communication and Cultural Literacy. Sydney.

Smith, Dorothy (1990): Texts, Facts and Femininity: Exploring the Relations of Ruling. London.

Spivak, Gayatri (1988): "Can the Subaltern Speak?". In: Nelson, Cary/Grossberg, Lawrence (eds.): Marxism and the Interpretation of Culture. London: 271-316.

Steedman, Carolyn (1992): "Culture, Cultural Studies and the Historians". In: Grossberg, Lawrence et. al. (eds.): Cultural Studies. New York/London: 613-621.

Storey, John (ed.) (1996): What is Cultural Studies? A Reader. London.

Thibault, Paul (1991): Social Semiotics as Praxis: text, social meaning making and Nabakov's Ada. Minneapolis.

Threadgold, Terry (1997): Feminist Poetics: Poeisis, Performance, Histories. London/New York.

Threadgold, Terry (2000): "Poststructuralism and Discourse Analysis". In: Lee, Alison/ Poynton, Cate (eds.): Culture and Text: 40-58.

Threadgold, Terry (2002): "Networks of Bodies and Texts: Accidents and/as Social Semiotics". Zeichenprocesse in Komplexen Systemen - Sign Processes in Complex Systems. Akten des 7. Internationalen Kongresses der International Association for Semiotic Studies (=Dresden Studies in Semiotics 4).

Tulloch, John (2000): Watching Television Audiences: Cultural Theories and Methods. London.

Tulloch, John/Moran, Albert (1986): A Country Practice: 'Quality Soap'. Sydney.

Tulloch, John/Lupton, Deborah. (1996): Television, Aids and Risk. Sydney.

Tulloch, John (1999): Performing Culture: Stories of expertise and the Everyday. London.

Turner, Victor (1987): The Anthropology of Performance. New York.

Valdes, Mario J./Miller, Owen (eds.) (1985): The Identity of the Literary Text. Toronto.

West, Cornel (1993): Keeping Faith. London/New York.

Wetherell, Margaret/Taylor, Stephanie/Yates, Simeon J. (2001): Discourse as Data: A Guide for Analysis. London.

Wetherell, Margaret (2001): "Debates in Discourse Research". In: Wetherell, Margaret. et. al. (eds.): Discourse Theory and Practice: A Reader: 380-399.

Whorf, Benjamin Lee (1956): Language, Thought and Reality: Selected Writings of Benjamin Lee Whorf. Edited by John B. Carroll. Cambridge/Massachusetts.

Williams, Kevin (1999): "Teaching Journalism in Britain". In: Philo, Greg (ed.): 271-281.

Willis, Paul (1977): Learning to Labour. Farnborough.

Willis, Paul (1978) : Profane Culture. London.

Wilson, Rob/Dirlik, Arif (eds.) (1995): Asia/Pacific as a Space of Cultural Production. Durham/London.

Wodak, Ruth/de Cilla, Rudolf/Reisigl, Martin/Liebhart, Karin (1999): The Discursive Construction of National Identity. Edinburgh. 
Wodak, Ruth/Meyer, Michael (eds.) (2001): Methods of Critical Discourse Analysis. London. Wodak, Ruth (2001): "What CDA is about - a summary of its history, important concepts and its developments". In: Wodak, Ruth/Meyer, Michael (eds): 1-13. 